MEDIA SOSIAL SEBAGAI MEDIUM KOMUNIKASI DAKWAH

\title{
Suharto Suharto
}

Institut Agama Islam Negeri Palu

Email: lectorsuharto@gmail.com

\section{Abstract:}

Indonesia is listed as the country with the most Twitter users in the world in 2010, more precisely amounted to $20.8 \%$ of internet users in the country or about 45 million Indonesians. The users of social media use twitter as a medium of da'wah (islamic preaching). Utilizing social media as a medium of da'wah means to affirm the existence of a preacher to always preach and transmit religious messages without being constrained by space and time. With social media facilities, a preacher also can make time efficient to interact with the audiences and sort content of da'wah which is more recent and fun.

و يعتبر اندونيسيا بلدا مع معظم مستخدي تويتز (twitter) في العالم في عام 2010، وعلى وجه الإنه

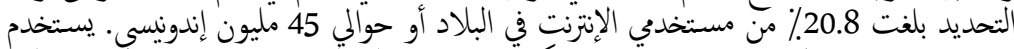

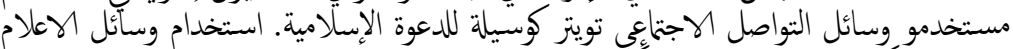

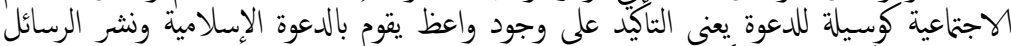

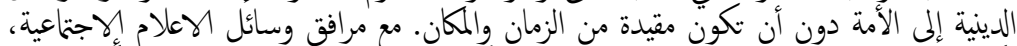

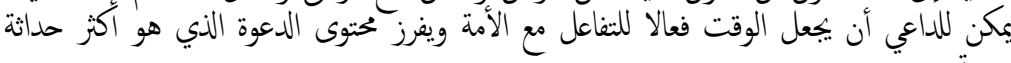

Kata Kunci: media sosial, medium, komunikasi dakwah

\section{Pendahuluan}

Berkomunikasi adalah syarat utama bagi seseorang atau siapapun dan profesi apapun jika ingin mencapai tujuannya. Dengan berkomunikasi, kita dapat melakukan interaksi tanpa batas, tidak terikat pada panjang dan pendeknya eksistensi bagi mereka yang sedang dan ingin saling bertukar informasi dan secamnya. Berkomunikasi 
adalah sebuah interaksi yang dapat terjadi bagi siapapun dan kapanpun, bisa antar pribadi, seorang dengan orang lain, seorang dengan banyak orang (kelompok atau golongan), atau kelompok atau organisasi dengan organisasi. Berkomunikasi berarti interkasi membangun kesepahaman untuk mencapai tujuan bersama.

Seiring waktu berjalan, dinamika dalam berkomunikasi pun ikut mewarnai hiruk pikuk dunia, dengan menggandeng teknologi informasi yang semakin berinovasi begitu cepat dan supercanggih, maka model komunikasi pun semakin variatif, bentuk dan pola komunikasi sedemikian beraneka macam dengan desain-desain terbaru. Tampak, dalam gerak laju revolusi teknologi dan media komunikasi, menyebabkan proses kerja komunikasi tidak hanya berpusat kepada mediamedia cetak dan elektronik seperti surat kabar dan televisi serta radio.

Pada tataran realitas, suguhan-suguhan media-media sosial semakin tak terbendung dan mengalir begitu deras merambah seluruh lapisan masyarakat. Perkembangan teknologi yang merupakan satu kesatuan yang bersenyawa dengan media sosial membuat masyarakat semakin melek informasi dan semakin tergoda untuk mempergunakannya. Kegaduhan akan efek dari hantaman badai revolusi teknologi informasi dan komunikasi yang bentuk dan variannya menjelma menjadi media-media sosial seperti facebook, twitter, WasApp, path, dan lainnya tidak hanya menghantam masyarakat urban, tetapi sekejap telah menyebar hingga ke kampung-kampung dan bahkan wilayah yang dulunya terisolasi kini telah dapat membangun terusan komunikasi melalui muntahan larva media sosial.

Virus revolusi teknologi informasi dan komunikasi tersebut, tidak hanya di dunia-dunia maju dan modern, tapi 
juga menjangkiti seluruh jagat raya, termasuk Indonesia. Kini, masyarakat Indonesia masuk kategori pengguna media sosial berbasis jaringan ataupun internet.

Seperti pendapat yang dikutip pada laman http://digilib.uinsby.ac.id/9761/4/bab\%201.pdf bahwa Berkembangnya teknologi informasi dan telekomunikasi di Indonesia sejak awal tahun 2000-an mendorong masyarakat Indonesia untuk lebih aktif di dunia maya saat ini, segala sesuatu dilakukan secara on-line baik itu komunikasi sosial, politik bahkan ekonomi. Internet kini tidak lagi digunakan sebatas meng-akses jejaring sosial saja. Namun, telah mendorong terciptanya media informasi yang bersifat realtime, tidak hanya itu media ini juga memiliki karakteristik yang berbeda dengan media massa konvensional, selain karena kemampuannya menyajikan informasi yang bersifat realtime, media internet juga memiliki kemampuan lain, yaitu kemudahan masyarakat yang mengakses untuk memberikan feedback secara langsung mengenai informasi yang disajikan ${ }^{1}$.

\section{Pendekatan Tulisan}

Paper ini ditulis berdasarkan kajian terhadap berbagai bahan pustaka online. Penelitian dengan menggunakan data online sudah biasa dalam kajian ilmu dakwah ${ }^{2},{ }^{3}, 4$ Dalam hal ini, penulis hanya menggunakan data sekunder melalui kajian

\footnotetext{
${ }^{1}$ Moh Ali Aziz, Ilmu Dakwah, Jakarta: Kencana Prenada Media Group. 2009) h.420

${ }^{2}$ Nurdin, N. (2012). Penggunaan Media Sosial Online dalam Berdakwah: Kemungkinan Adopsi dan Strategi Pemanfaatannya. Al-Mishbah: Jurnal Ilmu Dakwah dan Komunikasi, 8(1), 177-19

${ }^{3}$ Nurdin, N., \& Rusli. (2013). Spiritualising New Media: The Use of Social Media for Da'wah Purposes within Indonesian Muslim Scholars. Jurnal Komunikasi islam, 3(1), 1-21.

${ }^{4}$ Nurdin, N. (2014). To Dakwah Online or not to Dakwah Online. Da'i Dilemma in Internet Age. Al-Mishbah : Jurnal Ilmu Komunikasi dan Dakwah, 10(1), 21-33.
} 
pustaka yang mendalam terhadap berbagai literature dalam bidang ilmu dakwah dan komunikasi Islam, dan juga Internet. Data-data kualitatif yang bersumber dari media sosial dapat memperkaya pemahaman terhadap topik penelitian yang kita teliti ${ }^{5},{ }^{6}$. Dalam kajian-kajian ke Islaman sudah seharusnya kita befokus pada pengumpulan data lewat media online karena semakin banyak Muslim yang

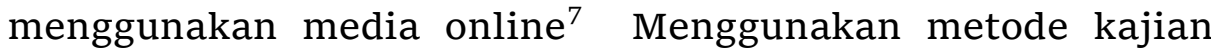
pustaka dalam melakukan suatu kajian guna menghasilkan sebuah karya ilmiah juga sudah biasa dilakukan oleh para akademisi. Metode ini dilakukan dengan cara mengakaji berbagai literature terdahulu guna melahirkan ide-ide baru untuk dimanfaatkan dimasa mendatang ${ }^{8}$. Dalam melakukan analisis berbagai data sekunder, penulis menggunakan pendekatan tematik dimana hasil kajian berbagai referensi di organisasikan menurut topik atau issue ${ }^{9}$ yang penulis teliti. Dengan kata lain isu-isu pemanfaatan media sosial selanjutnya di sesuaikan dengan pemanfaatannya dalam dakwah.

\section{Tsunami Media Sosial}

\footnotetext{
${ }^{5}$ Nurdin, N., Stockdale, R., \& Scheepers, H. (2013). The Use of Social Media to Gather Qualitative Data: A Case of Government E-Procurement Implementation and Use. Paper presented at the 24th Australasian Conference on Information Systems (ACIS).

6 Nurdin, N. (2017a). Research in Online Space: The Use of Social Media for Research Setting Jurnal Sistem Informasi (Journal of Information System), 13(1), 67-77.

7 Nurdin, N. (2017b). To research online or not to research online: using internet-based research in Islamic Studies context. Indonesian Journal of Islam and Muslim Societies, 7(1), 3154.

${ }^{8}$ Webster, J., \& Watson, R. T. (2002). Analyzing the Past to Prepare for the Future: Writing a Literature Review. MIS Quarterly, 26(2), 10.

${ }^{9}$ Labaree, R, Organizing Your Social Sciences Research Paper: The Literature Review. Retrieved 22 Oktober 2015, from USC Libraries http://libguides.usc.edu/c.php?g=235034\&p=1559822 (2013)
} 
Media sosial atau medsos merupakan trend masa kini dalam kehidupan ummat manusia di segala penjuru dunia. Medsos telah menjadi kebutuhan primer sehari-hari yang tidak terbatas ruang dan waktu, tidak mengenal tua ataupun muda, profesional, birokrasi, politisi dan lain-lainnya.

Berbagai varian dan inovasi medsos yang digandrungi dan menjadi medium utama mereka untuk berselancar di dunia maya seperti facebook, twitter, path, wassApp, telegram, email, BBM atau blackBerry Messanger, dan beberapa media-media sosial lainnya.

Everett M. Rogers (1986) mengatakan mengenai media sosial dalam Bungin yang mengatakan bahwa dalam hubungan komunikasi di masyarakat, dikenal empat era komunikasi, yaitu: era tulis, era media cetak, era media telekomunikasi, dan era media komunikasi interaktif. Dalam era terakhir media komunikasi interaktif dikenal media komputer, videotext, dan teletext, teleconferencing, TV kabel, dan sebagainya ${ }^{10}$.

Media sosial telah berhasil merebut hati masyarakat (terlebih di Indonesia), dengan kemampuannya menembus ruang-ruang isolasi hingga ke pelosok-pelosok dan pedalaman di segenap nusantara, bahkan mengalahkan dan sedikit mengesampingkan media sosial yang datang sebelumnya seperti tv dan radio. Di Indonesia, diprediksikan pengguna medsos salah satu tertinggi di dunia, seperti facebook yang diproyeksi telah digunakan sebanyak 21,5 juta, twitter 1,5 juta.

Seperti dikutip pada laman diskon.com pada tahun 2010 twitter berhasil menempati posisi satu pengguna

\footnotetext{
${ }^{10}$ http://www.zamrishabib.web.id/2014/12/peranan-media-sosialdalam-pengembangan.html
} 
twitter terbanyak di dunia yaitu $20.8 \%$ dan menyusul Brasil 20.5\%, Venuzela 19\% dan Amerika 11\%.

Melihat animo masyarakat Indonesia terhadap ketertarikannya menggunakan media sosial, sehingga berbagai steakholders baik pemerintahan, politisi, organisasi dan lembaga-lembaga pendidikan serta berbagai elemenelemen lainnya telah menjadikan medos sebagai medium utama dalam menjalankan aktivitas dan tugas-tugasnya serta memainkan peran dan fungsinya demi menunjang kinerja mereka.

Perkembangan medsos yang inhern dengan kemajuan teknologi informasi membuat fungsi medsos tidak hanya terbatas pada satu bidang saja seperti telpon dan SMS (Sort Messanger System), tetapi bahkan perkembangan tersebut membuatnya semakin multifungsi. Kini, medsos pun dapat berfungsi sebagai Tools Marketing dua arah yang paling cepat karena tidak terikat ruang dan waktu.

Dengan multifungsi tersebut, maka medos telah digunakan oleh masyarakat dunia dan ataupun organisasiorganisasi untuk menggalang massa. Di beberapa negara di dunia telah berhasil memanfaatkan medsos untuk penggalangan massa seperti di Republik Moldova dalam mendesain sebuah pergerakan untuk meruntuhkan rezim pemerintahan.

Olehnya itu, medsos merupakan medium komunikasi yang sangat dibutuhkan semua orang dalam kehidupannya. Bahwa, sebagai medium tersebut, medsos tidak hanya menjadi sarana efektif bagi pekerja politik dalam membangun dan mendesain kampanye dan komunikasi politik. Bukan pula menjadi prasyarat utama bagi para kaum profesional dan pebisnis dalam mengembangkan usahausahanya. Tetapi, semua orang, organ dan komunitas serta 
organisasi, baik besar maupun kecil, guru, dosen dan yang juga tatkala pentingnya bagi para muballigh, da'i dan ulama serta retor dakwah.

\section{Komunikasi Dakwah}

Komunikasi dakwah dapat diartikan bahwa sebuah proses interaksi penyampaian ajaran-ajaran agama yang dilakukan oleh seseorang kepada orang lain atau banyak orang, dengan menggunakan media dengan tujuan agar tercipta pemahaman yang berdampak kepada terjadinya perubahan pola pikir dan tingkahlaku komunikan.

Komukasi dapat dapat pula diartikan sebagai sebuah proses penyampaian informasi-informasi yang bersumber pada ajaran agama yang dilakukan oleh para retor-retor dakwah untuk mempengaruhi sikap dan persepsi obyek dakwah atau mad'u.

Komunikasi dakwah adalah komunikasi yang unsurunsurnya disesuaikan visi dan misi dakwah. Menurut Toto Tasmara, bahwa komunikasi dakwah adalah suatu bentuk komunikasi yang khas dimana seseorang komunikator menyampaikan pesan-pesan yang bersumber atau sesuai dengan ajaran al Qur'an dan Sunnah, dengan tujuan agar orang lain dapat berbuat amal shaleh sesuai dengan pesanpesan yang disampaikan.

Jadi dari segi proses komunikasi dakwah hampir sama dengan komunikasi pada umumnya, tetapi yang membedakan hanya pada cara dan tujuan yang akan dicapai. Adapun tujuan komunikasi pada umumnya yaitu mengharapkan partisipasi dari komunikan atas ide-ide atau pesan-pesan yang disampikan oleh pihak komunikator sehingga pesan-pesan yang disampaikan tersebut terjadilah perubahan sikap dan tingkah laku yang diharapkan, sedangkan tujuan komunikasi 
dakwah yaitu mengharapkan terjadi nya perubahan atau pembentukan sikap atau tingkah laku sesuai dengan ajaran agama Islam.

Harold D. Lasswell pernah mengungkapkan suatu pertanyaan untuk terpenuhinya suatu komunikasi melalui kata-kata bersayab, yaitu:who says what to whom in what channel with what effect.

Apabila pertanyaan tersebut diatas dapat kita jawab, maka komunikasi dapat kita jawab, komunikasi dakwahpun dapat memenuhi criteria tersebut:

Who

Says what
: Setiap pribadi muslim

: Kepada manusia pada?

In what Channel : Memakai media atau saluran dakwah apa saja yang syah secara hokum?

With what Effect :Terjadinya perubahan dalam pengetahuan

pemahaman dan tingkah laku atau perbuatan (amal shaleh) sesuai dengan pesan-pesan yang disampaikan oleh komunikasi.

Dengan demikian unsur-unsur serta proses komunikasi dakwah hampir sama dengan unsur-unsur dan proses komunikasi pada umumnya ${ }^{11}$.

Pelaksanaan komunikasi dakwah didasarkan pada ajaran agama Islam yaitu: alqur'an dan hadist. Dengan merujuk pada Firman Allah SWT:

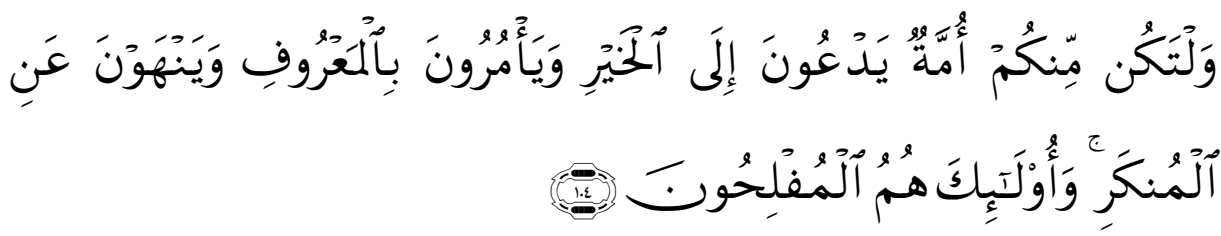
dakwah.html

http://emmarachmatika.blogspot.co.id/2013/o6/komunikasi- 
Terjemahnya:

"Dan hendaklah diantara kamu ada sebagian umat yang menyeru kepada kebajikan dan mencegah kemunkaran, merekalah orang-orang yang beruntung”. (Q.S AliImron:104) ${ }^{12}$

منر أمنكم منكر افليغير هبيدهفأنلم يستطع فبلسا نه فأن لم يستطعفبقلبهو ذلكاضعف الايمان

Artinya:

"Barang siapa diantara kamu melihat kemunkaran, maka hendaklah ia mengubahnya (mencegahnya) dengan tangannya, apabila ia tidak sanggup, maka dengan hatinya dan itulah selemah-lemahnya iman" (H.R. Bukhari). ${ }^{13}$

\section{Media Sosial Sebagai Medium Komunikasi Dakwah}

Media sosial adalah sebuah media online, dengan para penggunanya bisa dengan mudah berpartisipasi, berbagi dan menciptakan isi meliputi blog jejaring sosial, forum dan dunia virtual. Blog dan jejaring sosial merupakan bentuk media sosial yang paling umum digunakan oleh masyarakat di seluruh dunia ${ }^{14}$

Menurut Zamris Habib, Media sosial digunakan untuk bersosialisasi satu sama lain dan dilakukan secaraonline yang memungkinkan manusia untuk saling berinteraksi tanpa dibatasi ruang dan waktu. Media sosial dapat dikelompokkan menjadi beberapa bagian besar yaitu:

12 Departemen Agama RI, Alquran dan Terhemahnya, (Bandung: Jamaatul Ali Art, 2007), h. 63

13

${ }^{14}$ http://www.zamrishabib.web.id/2014/12/peranan-media-sosialdalam-pengembangan.html 
1. Social Networks, media sosial untuk bersosialisasi dan berinteraksi (Facebook, myspace, hi5, Linked in, bebo, dll)

2. Discuss, media sosial yang memfasilitasi sekelompok orang untuk melakukan obrolan dan diskusi (google talk, yahoo! M, skype, dll)

3. Share, media sosial yang memfasilitasi kita untuk saling berbagi file, video, music, dll (youtube, slideshare, feedback, flickr, crowdstorm, dll)

4. Publish, (wordpredss, wikipedia, blog, wikia, digg, dll)

5. Social game, media sosial berupa game yang dapat dilakukan atau dimainkan bersama-sama (koongregate, doof, pogo, cafe.com, dll)

6. MMO (kartrider, warcraft, neopets, conan, dll)

7. Virtual worlds (habbo, imvu, starday, dll)

8. Livecast ( $y$ ! Live, blog $t v$, justin $t v$, listream $t v$, livecastr, dll)

9. Livestream (socializr, froendsfreed, socialthings!, dll)

10. Micro blog (twitter, plurk, pownce, twirxr, plazes, tweetpeek, dll)

Media sosial Lanjut Habib, dapat membuat manusia berkomunikasi satu sama lain dimanapun dan kapanpun, tidak peduli seberapa jauh jarak mereka, dan tidak peduli siang atau pun malam. Saat ini media sosial memiliki dampak besar pada kehidupan di zaman modern. Seseorang yang asalnya "kecil" bisa seketika menjadi besar dengan media sosial, begitupun sebaliknya orang "besar" dalam sedetik bisa menjadi "kecil" dengan media sosial ${ }^{15}$.

Dalam mencapai tujuan komunikasi dakwah, maka seorang retor dakwah dituntut untuk mampu melakukan inovasi-inovasi dalam mendesain pola dakwah kepada

${ }^{15}$ Ibid 
masyarakat atau mad'u. Seorang da'i dituntut pula guna dapat menentukan medium-medium dakwah yang lebih variatif dan efektif yang tentunya yang kohern dengan zamannya.

Bahwa medium komunikasi dakwah di era modern dan multi media ini, tidak lagi seorang retor dakwah bertumpu pada pola dakwah klasik, dengan mengandalkan podiumpodium, tablik akbar dan tautsiah-tautsiah. Tidak lagi menunggu waktu atau musim berganti misalnya berdakwah atau berkhotbah di hari jum'at, safari ramadhan, tahlilan dan acara-acara seremoni lainnya.

Dengan hadirnya media sosial di tengah-tengah masyarakat, mengharuskan seorang retor dakwah harus dapat beradaptasi dengan medsos tersebut. Retor dakwah mesti melakukan desain ulang formulasi komunikasi dakwahnya, yang bisa mengimbangi perkembangan teknologi media yang berbasis jaringan internet.

Derry Febrian dalam laman DocSlide mengungkapkan bahwa Sosial Media Sebagai Ruang Dakwah Dari berbagai fungsi yang dapat dimanfaatkan melalui sosial media, hal ini memancing beberapa tokoh besar ulama untuk menggunakan sosial media sebagai alat untuk berdakwah. Sebut saja Ketua Umum Pengurus Besar Nahdlatul Ulama (PBNU), KH Said Aqil Siroj - akrab disapa Kang Said-. Kemudian anak perempuan Gus Dur, Yenny Zannuba Wahid atau yang lebih dikenal dengan Yenny Wahid (Direktur The Wahid Institute). Kemudian KH A. Musthofa Bisri -atau Gus Mus- yang menjabat sebagai Wakil Rais Aam Pengurus Besar Nahdlatul Ulama (PBNU). Kemudian tak ketinggalan juga $\mathrm{KH}$ Salahuddin Wahid -Gus Sholah-, yang merupakan pengasuh pondok pesantren Tebu Ireng, Jombang. Dan juga beberapa tokoh Nahdatul Ulama lainnya, seperti Alissa Wahid, dan 
masih banyak lagi. Tidak hanya saling bertukar sapa, bahkan beberapa tokoh menjawab pertanyaan seputar kajian fiqh dan agama melalui twitter. Diantara yang paling rajin menjawab pertanyaan dari masyarakat adalah @Gus_sholah. Hal seperti ini, yang sebenarnya dapat memacu pertumbuhan brand, baik secara kualitas maupun kuantitas jamaah (followers). Jumlah follower di twitter mereka pun tidak main-main. Karena self branding yang memang sudah kuat sebelumnya, jumlah follower dari masing-masing account tersebut bisa mencapai puluhan, bahkan ratusan ribu akun!. Misalnya akun twitter milik Gus Sholah. Pada akun @Gus_Sholah ini, terdapat 22.650 follower. Kemudian Yenny Wahid (@Yennywahid) yang memiliki 35.726 follower dan Aa Gym @aagym 75.331 follower. Sosial media dijadikan salah satu media dakwah yang sangat baik dan cepat, para tokoh besar ini juga ikut menaikkan brand perseption dari organisasi yang menjadi brand mereka. Integrated Media Sosial system dilakukan dengan semangat 'istiqamah', alias berkelanjutan dan berkesinambungan. Karena itu, tak hentihentinya jumlah follower terus bertambah ${ }^{16}$. Selain official sosial media, banyak juga organisasi-organisasi Islam membentuk accountaccount fans. Misalnya seperti @GUSDURians (Komunitas GUSDURian) dan @GusDurian_KDR (GusDurian’s Kediri). Keduanya adalah merupakan komunitas pecinta Gus Dur.Komunitas ini sendiri dibentuk sebagai semangat untuk meneruskan perjuanganperjuangan Gus Dur. Dan meskipun bukan merupakan akun resmi, jumlah follower nya juga tinggi, yakni mencapai 820 untuk GUSDURian dan 100 untuk Gusdurian Kediri. 3.2 Twitter sebagai Ruang Dakwah Aa Gym Apa yang dilakukan Aa Gym dengan Twitter, dalam ilmu

\footnotetext{
${ }^{16}$ http://dokumen.tips/documents/social-media-sebagai-mediakomunikasi-dakwah.html 
komunikasi disebut komunikasi massa. Dimana sang pembicara disebut komunikator, sementara yang membaca (followers) adalah khalayak atau komunikan. Di era masyarakat urban dimana waktu dan kesibukan menjadi penghalang untuk menghadiri mimbar dakwah atau tabligh akbar begitu langka. Dengan adanya twitter sebagai fasilitas abad 2.1, membaca dakwah bisa dilakukan dimana saja dan kapan saja. Aa Gym merupakan salah satu figur yang menginisiasi sosial media sebagai ruang dakwah ${ }^{17}$. Aa Gym memulai dakwah lewat Twitter sejak 13 Juni 2010 dan sekarang sudah memiliki 75 ribu pengikut yang akan membaca setiap isi tweet dakwahnya. 1000 tweet dakwahnya konstan berisikan tentang manajemen qolbu, sama seperti yang beliau dakwahkan lewat media massa lain seperti Televisi dan Radio.

\section{Penutup}

Meminjam pendapat Febrian, Indonesia tercatat sebagai negara dengan pengguna Twitter terbanyak di dunia pada 2010, lebih tepatnya berjumlah 20,8 \% dari pengguna internet di Tanah Air. Sementara, jumlah pengguna internet di Indonesia sudah mencapai 45 juta (kompas online). Melihat dari data jumlah pengguna internet di Indonesia, wajar saja apabila jumlah pengguna Twitter akan terus bertambah dan bertambah setiap harinya Ketika jumlah pengguna Twitter terus menerus bertambah, bisa dikatakan bahwa sebagian masyarakat Indonesia sudah melek terhadap kehadiran media baru, khususnya Twitter. Namun, masyarakat Indonesia yang baru melek akan adanya media baru seperti Twitter ini hanya terjadi pada kelompok

$$
{ }^{17} \text { Ibid }
$$


masyarakat menengah ke atas. Mengapa hanya kelompok masyarakat menengah ke atas yang melek terhadap kehadiran media baru? Mudah menjawabnya, karena hanya mereka lah yang mampu memiliki akses terhadap internet. Tapi pertanyaannya, apakah mereka (baca : kelompok masyarakat menengah ke atas) sudah benar-benar paham akan fungsi dan peranan media baru, seperti Twitter. Pertanyaannya adalah, mengapa sosial media terutama twitter melalui kicauan tweeps (sebutan bagi para pengguna akun twitter) dapat digunakan sebagai media dakwah? ${ }^{18}$

Keresahan Febrian di atas, saya ingin mencoba memberikan jawaban sederhana bahwa menyoal eksistensi media sosial yang dapat digunakan sebagai media dakwah, tentu kita berpulang kepada fungsi utama komunikasi. Bahwa media sosial yang merupakan komponen komunikasi tersebut memiliki fungsi menginformasikan, mendidik dan menghibur. Sehingga, bukanlah perkara sulit jika medsos kemudian dapat berfungsi sebagai medium dakwah, karena selain fungsi sejatinya, maka yang terpenting untuk dilihat bahwa pemilihan medsos sebagai medium dakwah merupakan tantangan dakwah yang harus dihadapi setiap retor dakwah.

Retor dakwah harus mampu membuat inovasi bentuk dan pola dakwah yang bersenyawa dengan media sosial, sebagai sebuah ikhtiar untuk menjaga konsistensi mereka di dalam melakukan dakwah islamiyah. Selain itu, yang terpenting adalah bahwa seorang retor dakwah tidak lagi bertumpu pada pola lama dan senantiasa melakukan pengembangan pola dakwah yang bisa secara interaktif dan berkesinambungan. 
Memanfaatkan medsos sebagai medium dakwah berarti meneguhkan eksistensi seorang retor dakwah untuk senantiasa berdakwah tiada henti, menularkan pesan-pesan agama tanpa sekat ruang dan waktu. Dengan fasilitas medsos pula retor dakwah bisa melakukan efisiensi waktu untuk melakukan interaksi dengan audiensnya serta dapat memilah konten dakwah yang lebih update dan menyenangkan.

\section{Daftar Pustaka}

Departemen Agama RI, Alqur'an dan Terjemahannya, (Bandung: Jamaatul Ali Art, 2007.

http://www.zamrishabib.web.id/2014/12/peranan-mediasosial-dalam-pengembangan.html

http://emmarachmatika.blogspot.co.id/2013/o6/komunikasidakwah.html

http://www.zamrishabib.web.id/2014/12/peranan-mediasosial-dalam-pengembangan.html

http://dokumen.tips/documents/social-media-sebagai-mediakomunikasi-dakwah.html.

Labaree, R, Organizing Your Social Sciences Research Paper: The Literature Review. Retrieved 22 Oktober 2015, from USC Libraries http://libguides.usc.edu/c.php?g=235034\&p=1559822 (2013)

Moh Ali Aziz, Ilmu Dakwah, (Jakarta: Kencana Prenada Media Group. 2009) h.420

Nurdin, N. (2012). Penggunaan Media Sosial Online dalam Berdakwah: Kemungkinan Adopsi dan Strategi Pemanfaatannya. AlMishbah: Jurnal Ilmu Dakwah dan Komunikasi, 8(1), 177-19

Nurdin, N., \& Rusli. (2013). Spiritualising New Media: The Use of Social Media for Da'wah Purposes within Indonesian Muslim Scholars. Jurnal Komunikasi islam, 3(1), 1-21. 
Nurdin, N. (2014). To Dakwah Online or not to Dakwah Online. Da'i Dilemma in Internet Age. Al-Mishbah : Jurnal Ilmu Komunikasi dan Dakwah, 10(1), 21-33.

Nurdin, N., Stockdale, R., \& Scheepers, H. (2013). The Use of Social Media to Gather Qualitative Data: A Case of Government EProcurement Implementation and Use. Paper presented at the 24th Australasian Conference on Information Systems (ACIS).

Nurdin, N. (2017a). Research in Online Space: The Use of Social Media for Research Setting Jurnal Sistem Informasi (Journal of Information System), 13(1), 67-77.

Nurdin, N. (2017b). To research online or not to research online: using internet-based research in Islamic Studies context. Indonesian Journal of Islam and Muslim Societies, 7(1), 31-54.

Webster, J., \& Watson, R. T. (2002). Analyzing the Past to Prepare for the Future: Writing a Literature Review. MIS Quarterly, 26(2), 10 . 